\title{
The Effect of Oral Administration of Aqueous and Organic Solvent Extracts From the Medicinal Wild Mushroom (Ganoderma Sp) on Performance and Health of Eimeria tenella-Infected Broiler Chickens
}

\author{
Ogbe, A.O., Zakariya A. \\ Department of Veterinary Medicine, University of Abuja, Nigeria \\ ogbeadamu@yahoo.com
}

\begin{abstract}
In a previous study, we reported that aqueous extract of the wild mushroom (Ganoderma sp) contained bioactive phytochemicals and has efficacy against caecal coccidiosis in broilers. In the current study, the efficacy of organic solvent extracts from the wild Ganoderma (butanol, methanol and ethyl acetate) against Eimeria tenella were evaluated in 6 weeks broiler chickens infected with 10,000 sporulated oocysts of E. tenella/ml/bird via the crop using insulin syringe. The birds were reared in separate wire cages (4 birds/group in duplicate) labelled $A=$ representing broilers not infected with $E$. tenella (negative control), $B=$ broilers infected but not treated (positive control), $C=$ broilers infected and treated with aqueous Ganoderma, $D=$ broilers infected and treated with methanol extract of Ganoderma, $E=$ broilers infected and treated with ethyl acetate extract of Ganoderma, $F=$ broilers infected and treated with butanol extract of Ganoderma, $G=$ broilers infected and treated with anticoccidia (amprolium) as positive control for comparison. All the treatments were administered $(2 \mathrm{ml} / \mathrm{bird})$ for 6 days in the morning and evening. Feed intake, body weight, faecal oocysts and haematological parameters were evaluated. The results showed that all the infected broilers in group $B, C, D, E, F$ and $G$ became dull and weak on day 5 post-infection. Broilers that were not infected remained apparently active and healthy (group A). By the 10th day post-infection the faecal droppings of infected broilers were bloody and watery. Group B, F and $G$ had morbidity and mortality of $2.5 \%$ respectively. Prior to treatment the oocysts detected were 6000 and 8000 in group D and $G$ respectively, followed by $E$ and $F$ (4000 each), H (4200), B (3500) and C (3350). There were no oocysts detected after the treatment except in broilers that were infected but not treated (group B), which had oocysts in their faecal dropping and intestinal scrapping. Broilers in group $G$ had higher feed intake, followed by group $F, D$ and $E$. They also had higher body weight gain. Group B had low packed cell volume (28.4\%) possibly due to haemorrhage caused by the coccidial infection. Feed intake, body weight gain and haematological responses were significantly different $(P<0.05)$. This study confirmed the need to exploit this macrofungus as a potential anticoccidial agent for control of coccidiosis in poultry.
\end{abstract}

Keywords: wild macrofungus, phytomedicine, anticoccidial activity, broiler chicken

\section{INTRODUCTION}

Coccidiosis is an acute or chronic infection caused by the protozoal parasites of the genus Eimeria, which multiply in the intestinal mucosa of chickens and produces severe tissue damage, resulting in bloody diarrhoea, blood loss, reduced growth, weight loss and increased susceptibility to other pathogens [1, 2, 3]. In Eimeria tenella infection, the coccidial parasites are confined to the caecum, and reproduction of the parasites results in the formation of unsporulated oocysts, which are shed in the faeces, thereby contaminating the poultry house (litter).

Broiler chickens of about 4 weeks of age are mostly susceptible and the infection is characterised by acute onset of bloody diarrhoea due to invasion of the caecal mucosal epithelium by second generation merozoites. Control strategies were based on strict hygienic measures combined with preventive medication using anticoccidial drugs such as amprolium (a thiamine analogue). Despite these control measures, coccidiosis continues to be a major constraint for efficient production of broilers in Nigeria. This may be due to resistance by the coccidial parasites or because some drugs only arrest the development of the parasites (coccidiostats). 
Coccidiosis is an economically important disease in poultry flocks such as broiler chickens, thereby prompting researchers to explore different control strategies to counter the disease in commercial poultry production enterprise. In Nigeria, a veterinary research finding by Ogbe et al [4], who reported that aqueous extract of the wild mushroom (Ganoderma sp) has anticoccidial effect against E. tenella infection in broiler chickens. Its health-promoting benefit was attributed to the presence of medicinally active bioactive compounds, minerals and amino acids [5, 6]. In China and Japan, the cultivated specie (Ganoderma lucidum) is used as food supplement and as medicine to improve various parameters of health and immune functions in humans [7,8]. The objective of this study was to investigate the effects of different organic solvent extracts of the wild macrofungus on E. tenellainfected broiler chickens.

\section{MATERIALS AND METHODS}

\subsection{Study site}

The study was conducted at the Veterinary Teaching Hospital of the Faculty of Veterinary Medicine, University of Abuja in Nigeria.

\subsection{Experimental birds}

One hundred day-old broiler chicks were obtained on $14^{\text {th }}$ April, 2015 from a reputable hatchery in Nigeria. The birds were randomly distributed into different treatment groups (A-H) of 6 chicks each in wire-mesh cages supported by wooden frames, each measuring $80 \times 100 \mathrm{~cm}$. Group A = represents broiler chickens not infected and not treated (negative control), B = broilers infected but not treated (positive control), $\mathrm{C}=$ broilers infected and treated with aqueous Ganoderma, D = broilers infected and treated with methanol extract of Ganoderma, $\mathrm{E}=$ broilers infected and treated with ethyl acetate extract of Ganoderma, F = broilers infected and treated with butanol extract of Ganoderma, $\mathrm{G}=$ broilers infected and treated with a standard anticoccidial drug (amprolium) as control for comparison.

\subsection{Collection of the wild medicinal macrofungus}

The wild mushroom or wood rot macrofungus (Ganoderma $\mathrm{sp}$ ) with red open caps were collected from wooden logs and tree stumps in Vom, Plateau and Nasarawa state, Nigeria. They were washed in distilled water, sun-dried, ground to powder using mortar and pestle and then blended using a local milling machine (unbranded). The mushroom powder was sun-dried for $24 \mathrm{~h}$ and then stored in plastic bucket at room temperature prior to use.

\subsection{Preparation of aqueous and organic solvent extracts}

Aqueous extracts from Ganoderma were prepared $(20 \% \mathrm{w} / \mathrm{v})$ by soaking in hot water boiled at $100^{\circ} \mathrm{C}$ for $3 \mathrm{~h}$ as described by Ogbe et al [4]. The extracts were sieved, solid matter was discarded and the filtrate allowed to cool to room temperature; bringing the concentration to $200 \mathrm{mg} / \mathrm{ml}$. Organic solvent extracts from the wild Ganoderma ( $20 \%$ w/v each of butanol, methanol and ethyl acetate extracts) were prepared by Soxhlet extraction using standard methods $[9,10,11]$. The dried mushroom powder was weighed (70 gram each for methanol, ethyl acetate and butanol extraction) using Metler balance (Toledo-PB 153) and then placed in a thimble and Soxhlet chamber with the organic solvents added $\left(350 \mathrm{ml}\right.$, each) and then steamed using rotator evaporator at $40^{\circ} \mathrm{C}$ for $24 \mathrm{~h}$ until the respective alcohol fraction completely evaporated. A standard anticoccidial drug (200 $\mathrm{mg} / \mathrm{ml}$, amprolium) was used as control for comparison. The extracts were stored in plastic bottles in refrigerator at $4^{\circ} \mathrm{C}$ prior to use.

\subsection{Experimental infection and treatment of broilers}

Broiler chickens in group B, C, D, E, F and G were infected with 10,000 sporulated oocysts of $E$. tenella per $\mathrm{ml} / \mathrm{bird}$ using insulin syringe introduced directly into the crop of each bird at 6 weeks of age in the morning hours between 10:30 and 11:30 a.m, on 19 May, 2015. At the $6^{\text {th }}$ day postinfection (PI), the broilers were administered orally with aqueous extract of Ganoderma (group C), butanol extract (D), methanol extract (E), ethyl acetate extract (F), and amprolium (G). Group A was not infected (negative control) but given only plain drinking water along with group B (positive control) for comparison. Treatments were done in the morning and evening by oral administration into the crop of each broiler ( $2 \mathrm{ml} / \mathrm{bird})$ for 6 consecutive days using insulin syringe (1/bird). 
The Effect of Oral Administration of Aqueous and Organic Solvent extracts From the Medicinal Wild Mushroom (Ganoderma Sp) on Performance and Health of Eimeria tenella-Infected Broiler Chickens

\subsection{Determination of live body weight}

Daily feed intake and body weight gain of the broilers were monitored and evaluated on weekly basis using a weighing balance (Hana-weighing scale) in the morning. All the birds were fed on broiler starter mash, $23 \%$ crude protein and $28000 \mathrm{kcal} / \mathrm{kg}$ metabolisable energy (1-4 weeks of age) and finisher mash, $20 \%$ crude protein and $2600 \mathrm{kcal} / \mathrm{kg}$ metabolisable energy (5-8 weeks of age). Feeders and drinkers were washed daily with hot water to reduce risk of contamination.

\subsection{Determination of haematological parameters}

Blood samples $(2 \mathrm{ml})$ were collected from each bird by jugular veni-puncture using sterile syringes and needles (1/bird) and the blood was immediately transferred into a set of sterile tubes containing anticoagulant, disodium-salt of ethylene diamine tetra-acetic acid (EDTA) for determination of packed cell volume (PCV), haemoglobin (Hb), red blood cells (RBC) and white blood cells (WBC). The microhaematocrit method and cyanmethaemoglobin method were used to determine packed cell volume (PCV) and haemoglobin ( $\mathrm{Hb})$, while the red blood cells (RBC) and the white blood cells (WBC) counts were determined using the Neubauer haemocytometer method [12].

\subsection{Collection of faecal samples and laboratory examination}

Faecal samples ( 2 gram) were collected from the broiler chickens in polythene bags for parasitological examination using McMaster counting chamber [13, 14]. Faecal samples from each group were thoroughly mixed in plastic bottles using spatula. One gram of the faecal sample was placed in a sterile bottle and homogenised by mixing with $1 \mathrm{ml}$ of flotation sodium chloride $(\mathrm{NaCl})$ salt solution to make a suspension and then mixed with $9 \mathrm{ml}$ of salt solution, sieved in gauze wire-mesh or muslin. The solid matter was discarded and the filtrate collected in clean sterile plastic tubes filled to the brim and a cover slip was placed on top taking care to exclude air bubbles. The bottles were allowed to stand upright for about $15 \mathrm{~min}$ to enable coccidia oocysts to float to the cover-slip before examination under a light microscope at times $(\times) 10$ and times $(x) 40$ magnifications. A portion of the positive sample only was used to fill the McMaster counting chamber and allowed to stand for about $15 \mathrm{~min}$ to enable oocysts to float and settle at the top of the chamber to facilitate identification and counting of the oocysts under the microscope using a differential counter. Absolute numbers of coccidia oocysts counted per $\mathrm{ml}$ of the solution were multiplied by a factor as described by [13].

\subsection{Post-mortem examination of carcasses and gross lesions}

Gross lesions were evaluated and organs were aseptically removed and weighed using a weighing scale and the values expressed in relation to body weight percentage (\%) per group.

2.10 Analyses of data - all the data generated were analyzed using descriptive statistic and analysis of variance. Mean values of feed intake, weight gain and haematological parameters were subjected to analysis of variance [15].

\section{RESULTS AND DISCUSSION}

\subsection{Composition and yield of organic extracts}

The prepared organic extracts appeared chocolate coloured, gelatinous and soluble in water, producing a greenish-yellow colour. Methanol extract of wild Ganoderma had the highest yield, $3.2 \mathrm{~g}$ (4.57\%), followed by butanol extract, $1.5 \mathrm{~g}(2.14 \%)$ and ethyl acetate extract, $1.0(1.43 \%)$. Phytochemical analysis of all the extracts showed presence of alkaloids and resins.

\subsection{Clinical observations and haematological responses of broilers}

Table 1 showed the clinical and haematological responses of broiler chickens before and after $E$. tenella infection and treatments. By day 5 after infection, all the broilers in the infected groups $(\mathrm{B}, \mathrm{C}$, D, E, F and G) appeared dull and weak and had reduced appetite. Their faecal droppings became bloody and some watery suggesting infection with coccidia parasites (E. tenella). Group B, F and G had morbidity and mortality of $2.5 \%$ respectively. Broilers that were not infected remained apparently active and healthy (group A). Prior to treatment of the broilers, the oocysts detected in their faecal samples were 3500 oocysts/gram faeces (group B), 3350 (group C), 6300 (group D), 4000 (group E), 4000 (group F), and 8000 (group G). The broiler chickens that were not infected (group A) were free of coccidial oocysts. After treatment for 6 days the faecal droppings of the broilers became negative in 
all the groups that were infected except the positive control (group A). However, there was reduction in the number of oocysts in broilers that were not treated (group B) but the presence of detectable oocysts in both the faecal dropping and intestinal scrapping $(+)$ indicates the birds were infected with coccidiosis. The faecal droppings and intestinal scrapings of the broilers that were administered aqueous Ganoderma and organic solvent extracts from Ganoderma were negative. Broilers that were not infected (group A) were also negative.

The results of haematological analysis (Table 1) showed that the packed cell volume (\%PCV) of the infected but not treated broilers (group B) were lower than the treated broilers (groups C, D, E, F and G) and those not infected (group A). Possibly, the low haematological value (28.4\%) was due to the damage or haemorrhage caused by the coccidial infection resulting into low PCV (anaemia). The red blood cells (RBC) and haemoglobin (Hb) levels were also low in this group (B), $2.18 \times 10^{12} / \mathrm{L}$ and $14.0 \mathrm{~g} / \mathrm{dL}$ respectively. PCV and $\mathrm{Hb}$ levels were higher in group $\mathrm{C}$ and $\mathrm{F}$. The white blood cells (WBC) count was higher in group F $\left(94.7 \times 10^{9} / \mathrm{L}\right)$ but lower in group $\mathrm{G}\left(74.1 \times 10^{9} / \mathrm{L}\right)$, followed by B $\left(84.1 \times 10^{9} / \mathrm{L}\right)$, and $\mathrm{A}\left(84.3 \times 10^{9} / \mathrm{L}\right)$. These findings may be connected with the depression of humoral immune responses (by IBD vaccination) or the reduction in resistance of the broilers as a result of coccidial infection. An increased white blood cells (WBC) was reported in normal albino rats that were administered oral preparation of organic solvent extracts from wild Ganoderma [6].

\subsection{Performance characteristics of broiler chickens}

Table 2 showed the feed intake of broiler chickens before and after E. tenella infection and treatments. The levels of feed intake of the broilers prior to infection were: $1.0 \mathrm{~kg} / \mathrm{bird}$ each (group A and B), 1.1 $\mathrm{kg} / \mathrm{bird}$ each $(\mathrm{C}, \mathrm{D}$ and $\mathrm{E}$ ), and $1.2 \mathrm{~kg}$ in group $\mathrm{F}$ and $\mathrm{G}$ respectively. In all the groups, the increase in feed intake was lower in group B, 5 days after infection (mean $=1.08 \mathrm{~kg} / \mathrm{bird}$ ) and after treatment (mean $=1.2 \mathrm{~kg} / \mathrm{bird})$. Generally, the feed intake was lower (mean $=3.28 \mathrm{~kg} / \mathrm{bird}$ ) in the broilers that were infected but not treated (group B) compared with group A (mean $=3.4 \mathrm{~kg} / \mathrm{bird}$ ) not infected and not treated broilers (Table 2). Figure 1 showed the levels of feed intake was highest in group $\mathrm{G}$ broilers infected and treated with amprolium (mean $=3.86 \mathrm{~kg} / \mathrm{bird}$ ), followed closely by group $\mathrm{F}$ infected and treated with ethyl-acetate extract (mean $=3.85 \mathrm{~kg} / \mathrm{bird}$ ), group E broilers infected and treated with methanolic extracts (mean $=3.64 \mathrm{~kg} / \mathrm{bird}$ ), group D infected and treated with butanolic extract (mean $=3.63 \mathrm{~kg} / \mathrm{bird}$ ), and group $\mathrm{C}$ infected and treated with aqueous extract of Ganoderma (mean $=3.58 \mathrm{~kg} / \mathrm{bird}$ ). Broilers in group B (infected but not treated) and those in group A (not infected and not treated) had the lowest levels of total feed intake, mean $=3.28$ and $3.4 \mathrm{~kg} / \mathrm{bird}$ respectively (Table 2, figure 1).

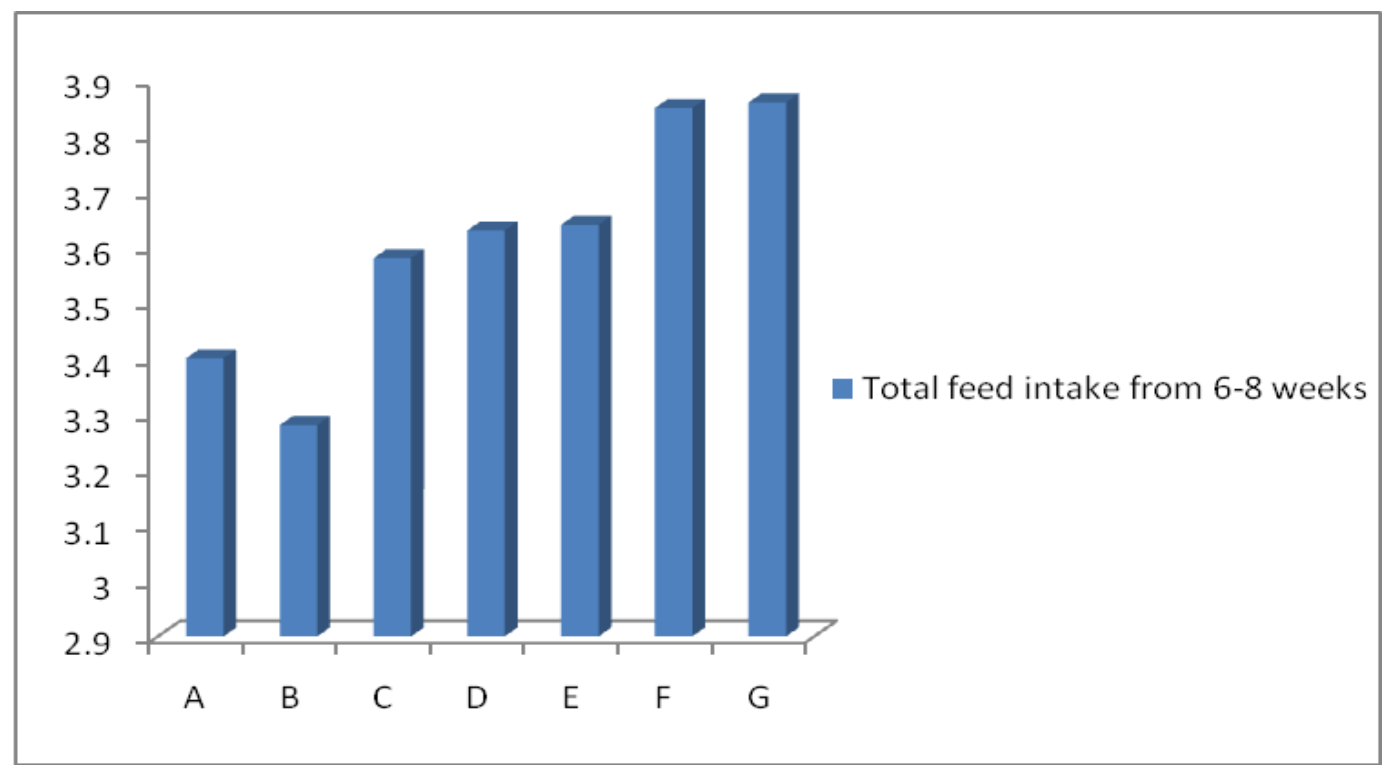

Figure 1. Mean total feed intake of broiler chickens after treatment (6-8 weeks).

Similarly, broilers in these groups followed the same pattern in terms of weight gained before and after infection and treatments (Table 2). Prior to infection, the initial mean weights in all the groups were: $1.0 \mathrm{~kg} / \mathrm{bird}$ each (group A, B, D and F), $0.99 \mathrm{~kg} / \mathrm{bird}$ each (group C and E) and G (0.98 kg/bird). By day 5 after the infection, the mean weight gain in the infected but untreated broilers (group B) and 
The Effect of Oral Administration of Aqueous and Organic Solvent extracts From the Medicinal Wild Mushroom (Ganoderma Sp) on Performance and Health of Eimeria tenella-Infected Broiler Chickens

all the infected and treated groups $(\mathrm{C}, \mathrm{D}, \mathrm{E}, \mathrm{F}$ and $\mathrm{G})$ became lower $(1.1-1.15)$ than the broilers that were not infected and untreated (group A), which had mean weight of $1.23 \mathrm{~kg} / \mathrm{bird}$ (Figure 2). At end of treatments, the level of mean weight gain remained lower in group B $(2.17 \mathrm{~kg} / \mathrm{bird})$ compared to the other groups (Figure 3). The overall mean weight gained by broilers in this group B was lower, mean $=1.17 \mathrm{~kg} /$ bird (Table 2).

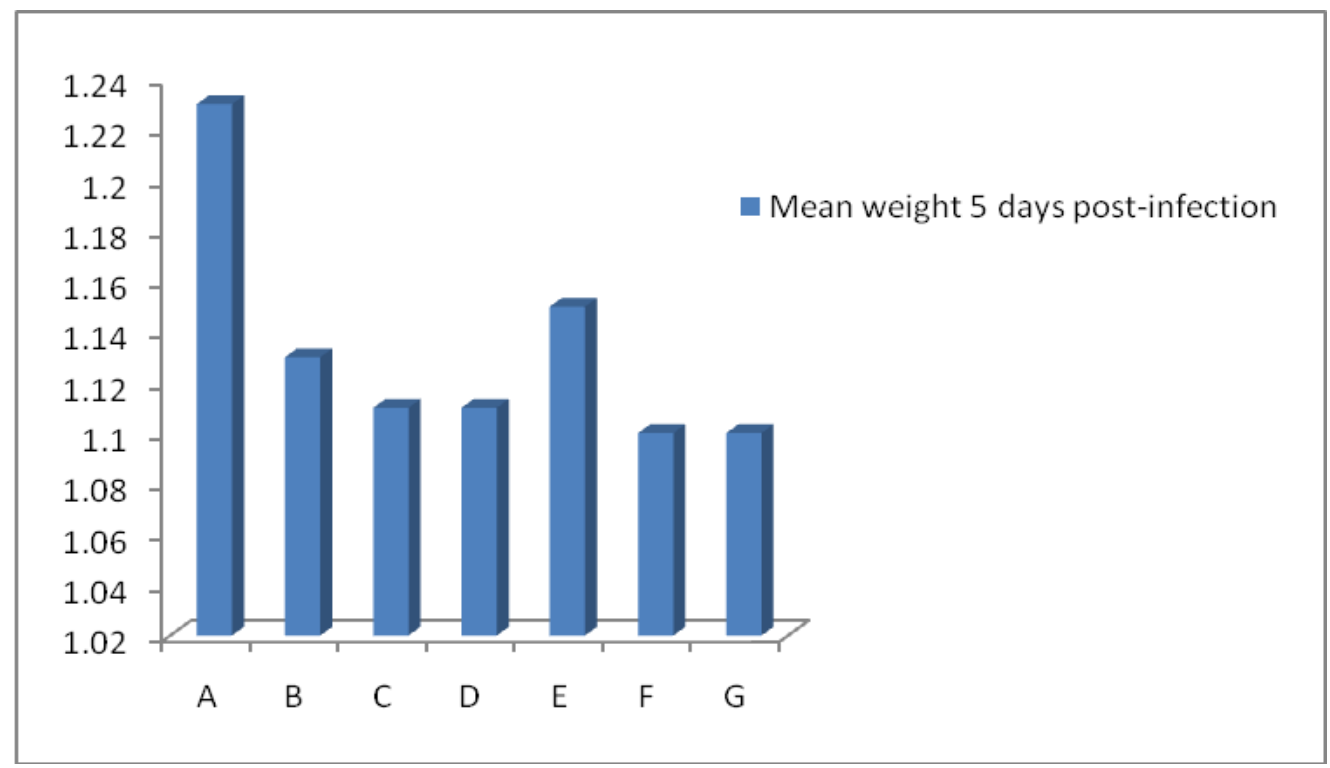

Figure 2. Mean weight gain of broilers 5 days after infection (7 weeks of age).

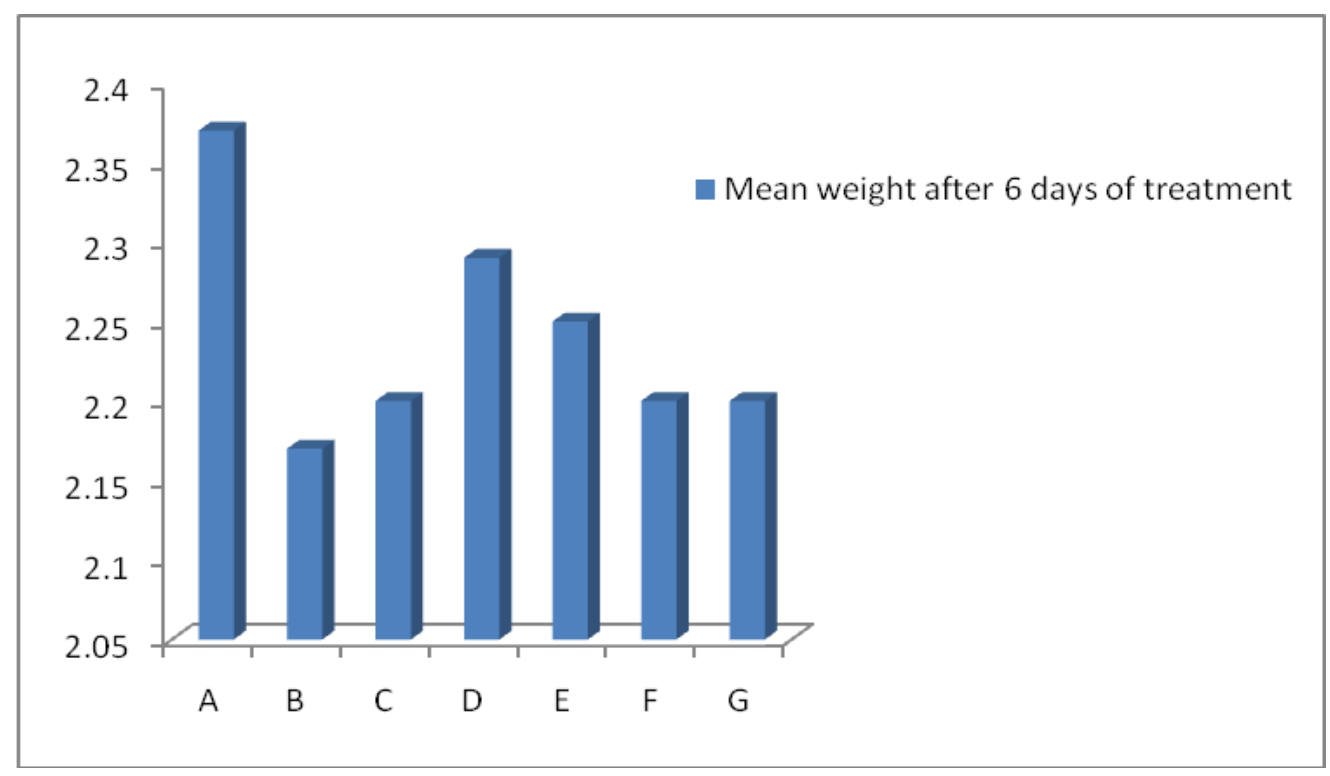

Figure 3. Mean weight of broilers after 6 days of treatment (8 weeks of age).

In all the groups, broiler chickens that were not infected with E. tenella (group A) recorded the highest mean weight, $2.37 \mathrm{~kg} / \mathrm{bird}$ (gained $=1.37 \mathrm{~kg}$ ), followed by butanol extract treated group D with $2.29 \mathrm{~kg} / \mathrm{bird}$ (gained $=1.2 \mathrm{~kg}$ ), and methanolic extract group E with $2.25 \mathrm{~kg} / \mathrm{bird}$ (gained $=1.26$ $\mathrm{kg}$ ). There were no significant differences between the mean weights of broilers treated with aqueous extract or ethyl acetate extract and amprolium $(\mathrm{P}>0.05)$. This study showed that broilers free from coccidial infection (coccidia-free broiler production) will improve growth performance in terms of weight gain. Secondly, treatment of $E$. tenella-infected broilers with organic solvent extracts of Ganoderma will promote weight gain in addition to their efficacy against cocidiosis. However, the low feed intake and body weights observed in group $\mathrm{G}$ may be due to the low dose rate of the anticoccidial drug $(2 \mathrm{ml} / \mathrm{bird})$. The choice of the dose rate was to maintain similarity with all the organic extracts used in this study. Previous studies $[4,16]$ showed significant feed intake and weight 
gain of Eimeria tenella-infected broilers administered adlibitum with either aqueous extract of Ganoderma or the standard anticoccidial drug (amprolium).

\subsection{Post-mortem lesions}

In this study, post-mortem lesions of three carcasses that died showed haemorrhage in the breast and thigh muscles (2/3), the caeca were ballooned and the mucosa was haemorrhagic (3/3) and the bursa of Fabricius was enlarged (3/3) and one (1/3) had haemorrhage. The broiler carcasses were from group A (enlarged and haemorrhagic bursa), B (haemorrhagic caeca and enlarged bursa), F (haemorrhagic caeca and enlarged bursa) and G (haemorrhages in the breast and thigh muscles). The haemorrhages in the caeca were caused by E. tenella (caecal coccidiosis) and the enlarged bursa was associated with infectious bursal disease. Coccidiosis is an acute or chronic infection caused by protozoal parasites of the genus Eimeria, which multiply in mucosa of the intestine (caecum) of chickens and produce severe tissue damage, resulting in haemorrhages and bloody diarrhoea. The lesions observed in coccidiosis are mostly confined in the intestinal mucosa of infected birds. The symptoms of coccidiosis include loss of blood (evident by the low PCV), reduced growth, weight loss and increased susceptibility to other pathogens $[1,2,3]$.

It was observed that vaccination of chickens against infectious bursal disease (IBD) using liveattenuated IBD vaccines can cause stress and consequently immunosuppression. Failure of protection of birds vaccinated with live-attenuated IBD vaccines can occur due to high maternal antibodies interference. In this study, the low performance of the broilers in terms of feed intake and weight gain may be attributed to the combined effects of infection with coccidial parasites and IBD immunosuppression or possibly failure of protection by vaccinations done against IBD (Gumboro disease). The bursa of Fabricius of birds regressed or atrophies as they grow older and after immunisation; if grossly enlarged bursa even after vaccination indicates birds were susceptible or prone to infectious bursal disease (Gumboro disease).

\section{Conclusion}

In conclusion, this study showed that Eimeria tenella infection of broiler chickens results in low feed intake, low body weight gain, low packed cell volume, faecal oocysts output and lesions in mucosa of the intestine (caeca). Oral administration of organic solvent extracts or aqueous extracts of the wild Ganoderma like amprolium improved performance of broilers in terms of weight gain and haematological responses. Further investigation on the anti-infective principles or mechanism of action of the bioactive compounds is recommended.

\section{ACKNOWLEDGEMENT}

The authors wish to thank the Director of the Veterinary Teaching Hospital of the Faculty of Veterinary Medicine, University of Abuja for permission to use the facilities in the Teaching Hospital for this research. Special thanks go to Dr. G.I. Dogo and his student in the department of Veterinary Parasitology, for the supply of the coocidia oocysts in this study.

Table 1. Clinical and haematological parameters of Eimeria tenella-infected broiler chickens administered organic solvent extracts of Ganoderma sp.

\begin{tabular}{|c|c|c|c|c|c|c|c|c|}
\hline \multirow[b]{2}{*}{ S/N } & \multirow[t]{2}{*}{ Parameters } & \multicolumn{7}{|c|}{ Group } \\
\hline & & $\mathbf{A}$ & B & C & D & $\mathbf{E}$ & $\mathbf{F}$ & G \\
\hline 1. & Clinical features: & & & & & & & \\
\hline a. & Temperament & Active & Dull & Dull & Active & Dull & Dull & Active \\
\hline b. & Morbidity (\%) & $1(25 \%)$ & $1(25 \%)$ & $0(0 \%)$ & $0(0 \%)$ & $0(0 \%)$ & $1(25 \%)$ & $1(25 \%)$ \\
\hline c. & Mortality (\%) & $1(25 \%)$ & $1(25 \%)$ & $0(0 \%)$ & $0(0 \%)$ & $0(0 \%)$ & $1(25 \%)$ & $1(25 \%)$ \\
\hline d. & Fecal dropping & Normal & $\begin{array}{c}\text { Bloody } \\
\text { (diarrhoea) }\end{array}$ & $\begin{array}{c}\text { Watery } \\
\text { (diarrhoea) }\end{array}$ & $\begin{array}{c}\text { Watery } \\
\text { (diarrhoea) }\end{array}$ & $\begin{array}{c}\text { Bloody } \\
\text { (diarrhoea) }\end{array}$ & $\begin{array}{c}\text { Watery } \\
\text { (diarrhoea) }\end{array}$ & $\begin{array}{c}\text { Watery } \\
\text { (diarrhoea) }\end{array}$ \\
\hline e. & $\begin{array}{l}\text { Oocyst/gram faeces before } \\
\text { treatment }\end{array}$ & Negative (0) & 3,500 & 3,350 & 6,300 & 4,000 & 4,000 & 8,000 \\
\hline f. & $\begin{array}{l}\text { Oocyst/gram faeces/ caecal } \\
\text { scrapping after treatment }\end{array}$ & Negative $(0)$ & Positive (+) & Negative $(0)$ & Negative (0) & Negative (0) & Negative (0) & Negative (0) \\
\hline 2. & Hematology: & & & & & & & \\
\hline a. & PCV (\%) before treatment & $28.30 \pm 0.55$ & $31.40 \pm 1.63$ & $22.00 \pm 8.45$ & $31.00 \pm 2.79$ & $31.00 \pm 0.62$ & $30.00 \pm 2.16$ & $31.40 \pm 2.89$ \\
\hline b. & $\begin{array}{l}\text { PCV (\%) after } \\
\text { Treatment }\end{array}$ & $30.30 \pm 0.61$ & $28.40 \pm 2.04$ & $35.50 \pm 0.67$ & $30.40 \pm 3.51$ & $32.20 \pm 7.34$ & $40.00 \pm 1.64$ & $32.20 \pm 4.17$ \\
\hline c. & $\begin{array}{l}\mathrm{RBC}\left(\mathrm{x} 10^{12} / \mathrm{L}\right) \text { before } \\
\text { treatment }\end{array}$ & $2.24 \pm 0.08$ & $2.58 \pm 0.12$ & $1.70 \pm 0.66$ & $2.42 \pm 0.18$ & $2.40 \pm 0.21$ & $2.27 \pm 0.28$ & $2.46 \pm 0.15$ \\
\hline d. & $\operatorname{RBC}\left(\times 10^{12} / \mathrm{L}\right)$ after & $2.28 \pm 0.04$ & $2.18 \pm 0.29$ & $2.65 \pm 0.18$ & $2.40 \pm 0.33$ & $2.49 \pm 0.64$ & $2.87 \pm 0.01$ & $2.47 \pm 0.28$ \\
\hline
\end{tabular}


The Effect of Oral Administration of Aqueous and Organic Solvent extracts From the Medicinal Wild Mushroom (Ganoderma Sp) on Performance and Health of Eimeria tenella-Infected Broiler Chickens

\begin{tabular}{|c|l|l|l|l|l|l|l|c|}
\hline \hline & treatment & & & & & & \\
\hline e. & $\mathrm{Hb}(\mathrm{g} / \mathrm{dL})$ before treatment & $14.10 \pm 0.71$ & $15.25 \pm 1.20$ & $10.70 \pm 4.10$ & $15.15 \pm 1.48$ & $15.20 \pm 0.57$ & $14.75 \pm 1.34$ & $15.45 \pm 0.78$ \\
\hline $\mathrm{f}$. & $\mathrm{Hb}(\mathrm{g} / \mathrm{dL})$ after treatment & $14.65 \pm 0.49$ & $14.00 \pm 1.13$ & $16.05 \pm 0.64$ & $14.75 \pm 1.48$ & $15.70 \pm 3.25$ & $18.45 \pm 0.07$ & $15.05 \pm 1.63$ \\
\hline $\mathrm{g}$. & $\begin{array}{l}\text { WBC }\left(\mathrm{x} 10^{9} / \mathrm{L}\right) \text { before } \\
\text { treatment }\end{array}$ & $85.12 \pm 1.45$ & $88.40 \pm 2.21$ & $61.11 \pm 2.39$ & $87.91 \pm 2.43$ & $85.71 \pm 2.92$ & $82.85 \pm 5.46$ & $74.90 \pm 1.74$ \\
\hline $\mathrm{h}$. & $\begin{array}{l}\text { WBC }\left(\mathrm{x} 10^{9} / \mathrm{L}\right) \text { after } \\
\text { treatment }\end{array}$ & $84.33 \pm 0.21$ & $84.10 \pm 1.60$ & $88.56 \pm 3.46$ & $88.53 \pm 0.23$ & $87.56 \pm 8.35$ & $94.65 \pm 0.28$ & $74.11 \pm 1.23$ \\
\hline
\end{tabular}

Group $A=$ represents broilers not infected and not treated (negative control), $B=$ broilers infected but not treated (positive control), $\mathrm{C}=$ broilers infected and treated with aqueous extract of Ganoderma, $\mathrm{D}=$ broilers infected and treated with methanol extract, $\mathrm{E}=$ broilers infected and treated with ethyl acetate extract, $\mathrm{F}=$ broilers infected and treated with butanol extract, and $G=$ broilers infected and treated with amprolium.

Table 2. Performance characteristics of Eimeria tenella-infected broiler chickens administered organic solvent extracts of wild Ganoderma sp.

\begin{tabular}{|c|c|c|c|c|c|c|c|c|c|}
\hline $\mathbf{S} / \mathbf{N}$ & Parameters & \multirow{2}{*}{$\begin{array}{c}\text { Age } \\
\text { (weeks) }\end{array}$} & \multicolumn{7}{|c|}{ Group } \\
\hline 1. & Mean feed intake of broilers (kg/bird) & & $\mathbf{A}$ & B & $\mathbf{C}$ & D & $\mathbf{E}$ & $\mathbf{F}$ & G \\
\hline a. & Initial mean feed intake before infection & 6 & $\begin{array}{c}1.00 \\
\pm 0.03\end{array}$ & $\begin{array}{l}1.00 \\
\pm 0.0\end{array}$ & $\begin{array}{c}1.10 \\
\pm 0.01\end{array}$ & $\begin{array}{c}1.10 \\
\pm 0.10\end{array}$ & $\begin{array}{c}1.10 \\
\pm 0.10\end{array}$ & $\begin{array}{r}1.20 \\
\pm 0.04\end{array}$ & $\begin{array}{l}1.20 \\
\pm 0.0\end{array}$ \\
\hline b. & Mean feed intake after 5 days post-infection & 7 & $\begin{array}{c}1.10 \\
\pm 0.01\end{array}$ & $\begin{array}{c}1.08 \\
\pm 0.10\end{array}$ & $\begin{array}{l}1.18 \\
\pm 0.1\end{array}$ & $\begin{array}{c}1.22 \\
\pm 0.03\end{array}$ & $\begin{array}{l}1.22 \\
\pm 0.0\end{array}$ & $\begin{array}{c}1.29 \\
\pm 0.02\end{array}$ & $\begin{array}{c}1.27 \\
\pm 0.10\end{array}$ \\
\hline c. & Mean feed intake after 6 days of treatment & 8 & $\begin{array}{c}1.30 \\
\pm 0.10\end{array}$ & $\begin{array}{l}1.20 \\
\pm 0.1\end{array}$ & $\begin{array}{c}1.30 \\
\pm 0.02\end{array}$ & $\begin{array}{c}1.31 \\
\pm 0.10\end{array}$ & $\begin{array}{c}1.32 \\
\pm 0.20\end{array}$ & $\begin{array}{c}1.36 \\
\pm 0.20\end{array}$ & $\begin{array}{c}1.39 \\
\pm 0.10\end{array}$ \\
\hline & Total mean feed intake from 6-8 weeks & 6-8 & 3.4 & 3.28 & 3.58 & 3.63 & 3.64 & 3.85 & 3.86 \\
\hline 2. & Mean body weight of broilers (kg/bird) & & & & & & & & \\
\hline a. & Initial mean weight before infection & 6 & $\begin{array}{l}1.00 \\
\pm 0.0\end{array}$ & $\begin{array}{c}1.00 \\
\pm 0.02\end{array}$ & $\begin{array}{c}0.99 \\
\pm 0.02\end{array}$ & $\begin{array}{c}1.00 \\
\pm 0.01\end{array}$ & $\begin{array}{c}0.99 \\
\pm 0.05\end{array}$ & $\begin{array}{c}1.00 \\
\pm 0.02\end{array}$ & $\begin{array}{c}0.98 \\
\pm 0.04\end{array}$ \\
\hline b. & Mean weight after 5 days post-infection & 7 & $\begin{array}{c}1.23 \\
\pm 0.09\end{array}$ & $\begin{array}{c}1.13 \\
\pm 0.22\end{array}$ & $\begin{array}{c}1.10 \\
\pm 0.11\end{array}$ & $\begin{array}{c}1.10 \\
\pm 0.07\end{array}$ & $\begin{array}{c}1.15 \\
\pm 0.16\end{array}$ & $\begin{array}{r}1.10 \\
\pm 0.06\end{array}$ & $\begin{array}{c}1.10 \\
\pm 0.05\end{array}$ \\
\hline c. & Mean weight after 6 days of treatment & 8 & $\begin{array}{c}2.37 \\
\pm 0.07\end{array}$ & $\begin{array}{c}2.17 \\
\pm 0.15\end{array}$ & $\begin{array}{c}2.20 \\
\pm 0.09\end{array}$ & $\begin{array}{c}2.29 \\
\pm 0.01\end{array}$ & $\begin{array}{c}2.25 \\
\pm 0.18\end{array}$ & $\begin{array}{r}2.20 \\
\pm 0.04\end{array}$ & $\begin{array}{c}2.20 \\
\pm 0.04\end{array}$ \\
\hline & Mean weight gain from 6-8 weeks & 6-8 & 1.37 & 1.17 & 1.21 & 1.20 & 1.26 & 1.20 & 1.22 \\
\hline
\end{tabular}

Group $A=$ represents broilers not infected and not treated (negative control), $B$ =broilers infected but not treated (positive control), $\mathrm{C}=$ broilers infected and treated with aqueous extract of Ganoderma, $\mathrm{D}=$ broilers infected and treated with methanol extract, $\mathrm{E}=$ infected and treated with ethyl acetate extract, $\mathrm{F}=$ broilers infected and treated with butanol extract, and $\mathbf{G}=$ broilers infected and treated with amprolium.

\section{REFERENCES}

[1] Canning, E.W. and Anwar, M.A. (1968): Studies on meiotic division in coccidial parasites. Journal of Protozoology, 15: 290-298.

[2] Chapman, H.D. (1989): The sensitivity of field isolates of Eimeria tenella to anticoccidial drugs in chickens. Research in Veterinary

Science, 47: 125-128.

[3] Chapman, H.D. and Shirley, M.W. (2003): The Houghton strain of Eimeria tenella: a review of the type strain selected for genome sequencing. Avian Pathology, 31: 115-127.

[4] Ogbe, AO., Atawodi, S.E., Abdu, P.A., Sannusi, A. and Itodo, A.E. (2009a): Changes in weight gain, faecal oocyst count and packed cell volume of Eimeria tenella-infected broilers treated with a wild mushroom (Ganoderma lucidum) aqueous extract. South African Journal of Veterinary Association, 80(2): 97-102.

[5] Ogbe, A.O; Ditse, U; Echeonwu, I; Ajodoh, K; Atawodi, S.E. and Abdu, P.A. (2009b): Potential of a wild mushroom, Ganoderma sp, as feed supplement in chicken diet: Effect on performance and health. International Journal of Poultry Science, 8(11): 1052-1057.

[6] Shamaki, B.U., Ogbe, A.O., Abdulrahman, F.I. and Sandabe, U.K. (2014): Haematological parameters in normal albino rats following oral administration of methanolic extract of wild Ganoderma sp. International Journal of Pharmacological Screening Methods, 4(2): 94-99. 
[7] Oei, P. (2003): Benefits of mushrooms. In: Mushroom cultivation, 3rd Edition. Technical Centre for Agricultural and Rural Cooperation (CTA), Backhuys, Leiden: 1-7.

[8] Wachtel-Galor, S., Tomlinson, B. and Benzie, I.F. (2004): Ganoderma lucidum (Lingzhi), a Chinese medicinal mushroom: biomarker responses in a controlled human supplementation study. British Journal of Nutrition, 91: 263-269.

[9] Shamaki, B.U, El-Yuguda, A.D., Abdulrahman, F.I., Ogbe, A.O. and Sandabe, U.K. (2013): Invitro inhibition of neuraminidase activity of influenza virus (H5N2) by methanolic soluble fraction of Ganoderma lucidum extract. International Journal of Modern Biology and Medicine, 4(3): 147-154.

[10] Trease, G.E. and Evans, W.C. (1997): Plant phytochemical analyses. Textbook of Pharmacognosy, 12th Edn. W.B. Saunders Company Limited, London, UK., 13-53.

[11] Olajide, O., Abayomi, O., Fatokun O., Akande, T. and Ibrahim, I. (2013): The chemical composition of essential oil from root of Cissampelos owariensis and free radicals scavenging of its root extract. AJPAC, 7(6): 225-230.

[12] Esievo, K.A.N. and Saror, D.I. (1992): A laboratory manual in veterinary clinical pathology, First Edition. Faculty of Veterinary Medicine, Ahmadu Bello University, Zaria, Nigeria.

[13] Jaroslav, V., Miloslav, P., Daniela, L., Zuzana, C., Marie, K., Ivana, J. and Iva, L. (2013): The concentration of McMaster Technique is suitable for quantification of coccidian oocysts in bird droppings. Pak. Vet. Journal, 33(3): 291-295.

[14] Long, P.L. and Powell, J.G. (1958): Counting oocysts of chicken coccidia. Laboratory Practice, 7: 515 .

[15] Olawuyi, J.F. (1996): Biostatistics: a foundation course in health sciences. First Edition. University College Hospital, Tunji Alabi Printing, Total Garden, Ibadan, Nigeria: 1-221.

[16] Ogbe, A.O. (2008): The use of Ganoderma lucidum in improvement of antibody response to infectious bursal disease vaccination and treatment of caecal coccidiosis in chickens. Ph.D Dissertation. Department of Veterinary Surgery and Medicine, Ahmadu Bello University, Zaria, Nigeria, 73-97.

\section{AUTHOR'S BIOGRAPHY}

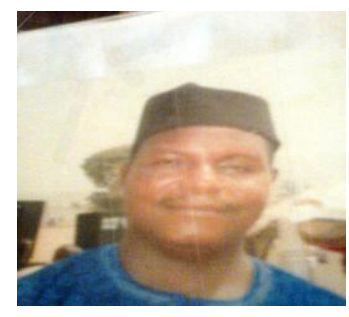

Dr. Adamu O. Ogbe, is a Senior Lecturer in the Department of Veterinary Medicine of the Faculty of Veterinary Medicine, University of Abuja, Nigeria. He started his professional career at the National Veterinary Research Institute (NVRI), Vom in Nigeria, where he was involved in research and teaching at the Federal College of Animal Health \&Production Technology (FCAH \& PT), NVRI, Vom from1994 to 2010. He later transferred his services to Nasarawa State University Keffi and later to the Faculty of Veterinary Medicine, University of Abuja in 2013. He has many publications in international journals with over 60 citations. 